\title{
Pathways for the Oxidation of Aromatic Compounds by Azotobacter
}

\author{
By C. HARDISSON*, J. M. SALA-TREPAT AND R. Y. STANIER \\ Centre de Recherches Hydrobiologiques, C.N.R.S. \\ $9 I-$ Gif sur Yvette, France \\ (Accepted for publication I2 July 1969)
}

SUMMARY

The metabolic pathways used by members of the genus Azotobacter for the oxidation of benzoate and $p$-hydroxy-benzoate have been investigated. $A$. chroococcum, $A$. vinelandii and $A$. beijerinckii oxidize benzoate via catechol, which is further metabolized by meta cleavage. The same species oxidize $p$-hydroxybenzoate via protocatechuate, which is dissimilated through the $\beta$-ketoadipate pathway.

\section{INTRODUCTION}

During recent years biochemical investigations of the oxidative degradation of aromatic compounds by several genera of aerobic bacteria (summarized by Ribbons, 1966) have revealed that many of these substrates are metabolized through the diphenols, protocatechuate and catechol. These intermediates are converted to aliphatic compounds by oxygenative ring cleavage. Two methods of ortho-diphenol cleavage have been demonstrated in bacteria (Dagley, Evans \& Ribbons, I960): (I) ortho cleavage, oxidative fission of the bond between carbon atoms bearing the hydroxyl groups; (2) meta cleavage, rupture of the aromatic structure at the $\mathrm{C}-\mathrm{C}$ bond adjacent to the ortho-diphenol group. Completely different metabolic pathways result from these two modes of ring cleavage.

The ability of Azotobacter species to utilize aromatic compounds has been long known (Winogradsky, 1932; Guittonneau \& Chevalier, 1939). However, besides a report on the metabolism of benzoate to catechol by Azotobacter vinelandii (Voets, 1958), the metabolic pathways utilized by Azotobacter species for the oxidation of aromatic substrates have not so far been investigated. We describe here the pathways used for the metabolism of benzoate and p-hydroxybenzoate by several Azotobacter species.

\section{METHODS}

Organisms. The strains utilized have the following origins and designations. Azotobacter chroococcum strain 203, A. vinelandii strain 206 and A. agilis strain 140 were derived from the Colección Española de Cultivos Tipo, C.S.I.C., Madrid, Spain. $A$. chroococcum strain v, $A$. vinelandii strains C-I 4 and $\mathrm{C}-\mathrm{I} 5$ and $A$. beijerinckii strain $\mathrm{V}$ were the gift of Professor J. P. Voets (Agricultural University, Ghent, Belgium). A. chroococcum strain IP and $A$. vinelandii strain IP were from the Department de

* Present address: Departmanento de Microbiología, Facultad de Ciencias, Universidad de Salamanca, Salamanca, Spain.

Vol. 58, No. 3 was issued 30 January 1970 
Microbiologie du Sol, Institut Pasteur, Paris, France. Beijerinckia derxii strain B-30, $B$. indica strain B-I 7 and $B$. fluminensis were provided by $\mathrm{Dr}$ F. Hilger (Institut Agronomique de l'Etat, Gembloux, Belgium). $A$. chroococcum, strain P $\beta-203$, is a permeability mutant (able to grow on $\beta$-ketoadipate) isolated by spreading about $10^{8}$ wild-type organisms of $A$. chroococcum strain 203 on plates of basal agar medium containing $5 \mathrm{~mm}$ - $\beta$-ketoadipate, as described by Ornston (I966c).

Chemicals and enzyme reagents. $\beta$-Carboxy-cis,cis-muconic acid, $( \pm)$-muconolactone, cis,cis-muconic acid and $\beta$-ketoadipic acid were synthesized by $\mathrm{Dr} \mathrm{M}$. Robert-Gero. Succinyl-CoA was synthesized by the method of Stadtman (I957). Purified preparations of $\beta$-ketoadipate enol-lactone hydrolase, muconolactone isomerase and muconate lactonizing enzyme, required for enzyme assays, were kindly provided by Dr G. D. Hegeman (Department of Bacteriology and Immunology, University of California, Berkeley, California, U.S.A.). All other reagents and chemicals were of the highest grade available commercially.

Growth media and culture conditions. A modification of Burk nitrogen-free medium (Burk \& Lineweaver, I930) was used for the cultivation of the Azotobacter strains. It had the following composition (mg./l.) $: \mathrm{KH}_{2} \mathrm{PO}_{4}, 200 ; \mathrm{K}_{2} \mathrm{HPO}_{4} 800 ; \mathrm{MgSO}_{4} \cdot 7 \mathrm{H}_{2} \mathrm{O}$, 200; $\mathrm{CaCl}_{2}, 50 ; \mathrm{FeSO}_{4} \cdot 7 \mathrm{H}_{2} \mathrm{O}, \mathrm{IO} ; \mathrm{MnSO}_{4} . \mathrm{H}_{2} \mathrm{O}, \mathrm{I} ; \mathrm{Na}_{2} \mathrm{MoO}_{4} \cdot 2 \mathrm{H}_{2} \mathrm{O}, 2,5$. To avoid precipitate formation, the solution of $\mathrm{CaCl}_{2}$ was autoclaved separately and added immediately before inoculation. The final $\mathrm{pH}$ value of this medium was $7 \cdot 3$.

The organic carbon and energy sources were added to the mineral basal medium as concentrated sterile stock solutions, to yield the following final concentrations: disodium succinate, $20 \mathrm{~mm}$; sodium $p$-hydroxybenzoate, $15 \mathrm{~mm}$; sodium benzoate, $15 \mathrm{~mm}$; sodium shikimate, Io mM; disodium $\beta$-ketoadipate, $10 \mathrm{~mm}$; sodium protocatechuate, $8 \mathrm{~mm}$. For solid media, all organic substrates were used at a concentration of $\mathrm{IO} \mathrm{mM}$ and $\mathrm{I} \%(\mathrm{w} / \mathrm{v})$ agar was added. Chemically unstable substrates (e.g. sodium protocatechuate, disodium $\beta$-ketoadipate) were sterilized by filtration through Millipore filters and used immediately. Stock cultures of Azotobacter strains were maintained at room temperature on agar slopes containing succinate Io $\mathrm{mm}$ as the carbon source and were transferred monthly. Cultures for experimental work were incubated at $28^{\circ}$.

Liquid cultures were incubated aerobically with mechanical agitation. Small liquid cultures were grown in volumes of $50 \mathrm{ml}$. in $250 \mathrm{ml}$. conical flasks. When enzyme concentrations were to be determinated in cell-free extracts, cultures were grown in volumes of $400 \mathrm{ml}$. in 21 . Fernbach flasks. Fernbach flasks have a broad base and a long-narrow neck and are particularly suitable for growing aerobic organisms in liquid media. In liquid cultures a $10 \%(\mathrm{v} / \mathrm{v})$ inoculum of a culture in the early $\log$ phase growing with succinate $20 \mathrm{~mm}$ was used. Growth was estimated by measuring the extinction of the culture at $660 \mathrm{~m} \mu$ in a Bausch and Lomb Spectronic-20 Colorimeter. An extinction of $\mathrm{I} \cdot 0$ was equivalent, for an exponentially growing culture, to about $2 \times 10^{8}$ organisms $/ \mathrm{ml}$, for Azotobacter chroococcum strain $203 ; 3 \times 10^{8}$ organisms $/ \mathrm{ml}$, for $A$. vinelandii strain $206 ; 0.7 \times 10^{3}$ organisms $/ \mathrm{ml}$., for $A$. beijerinckii strain $\mathrm{v}$.

Beijerinckia cultures were grown on the mineral basal medium described by De Ley \& Park (I966), supplemented with an appropriate carbon source; stock cultures were maintained on slope of potato glucose agar.

Mechanism of ring fission. Organisms growing exponentially on $p$-hydroxybenzoate or benzoate were harvested by centrifugation, washed and resuspended in $20 \mathrm{~mm}$ - 
tris $+\mathrm{HCl}$ buffer $(\mathrm{pH} 8 \cdot 0)$. The method of Hosokawa as described by Stanier, Palleroni $\&$ Doudoroff (1966) was used with these suspensions to determine the mechanism of ortho-diphenol cleavage.

Manometric techniques. Vegetative organisms were harvested during exponential growth by centrifugation at $7000 \mathrm{~g}$ for $\mathrm{I} 5 \mathrm{~min}$. at $0^{\circ}$, washed twice in $20 \mathrm{~mm}$-sodium potassium phosphate buffer $\left(\mathrm{pH}_{7} \cdot 0\right)$ and resuspended in the same buffer. The suspension was adjusted to give an extinction of approximately 0.3 at $660 \mathrm{~m} \mu$ in the Spectronic-20 Colorimeter. Rates of oxygen uptake were determined at $30^{\circ}$ with a Warburg type respirometer. The rates are expressed as $\mathrm{Q}_{\mathrm{o}_{2}}\left(\mu \mathrm{l} . \mathrm{O}_{2} / \mathrm{hr} / \mathrm{mg}\right.$. dry weight), corrected for endogenous respiration. Bacterial cell mass of the suspensions was determined from a standard curve relating extinction to dry weight. The contents of Warburg vessels were: $1 \mathrm{ml}$. (equivalent to $150-300 \mu \mathrm{g}$. dry weight) of cell suspension in the main compartment; $0.2 \mathrm{ml}$. of $20 \%(\mathrm{w} / \mathrm{v}) \mathrm{NaOH}$ in the centre well, and Io $\mu$ mole substrate in the side arm. Sodium potassium phosphate buffer $(20 \mathrm{mM}, \mathrm{pH} 7 \cdot 0)$ to a total volume of $2 \mathrm{ml}$. was added to the main compartment. The gas phase was air.

Preparation of cell-free extracts. Rod-shaped organisms were removed from cultures by centrifugation at $7000 \mathrm{~g}$ for $\mathrm{I} 5 \mathrm{~min}$. at $\mathrm{o}^{\circ}$. Cysts of Azotobacter beijerinckii strain $\mathrm{v}$, were also harvested to compare enzymic activities of resting organisms with vegetative ones. The organisms were washed in chilled $20 \mathrm{~mm}$-tris $+\mathrm{HCl}$ buffer $(\mathrm{pH} \mathrm{8.0)}$ containing Io $\mu \mathrm{M}-\mathrm{Mg}$-EDTA and centrifuged at $10,000 \mathrm{~g}$ for $45 \mathrm{~min}$. at $0^{\circ}$. The yield of organisms was between 0.8 and $\mathrm{I} \cdot 5 \mathrm{~g}$. (wet weight) $/ 1$. culture, depending on substrate and organism. The pellets were resuspended as 25 to $30 \%$ (wet weight/ volume) suspensions of organism in the same buffer and stored at $-20^{\circ}$.

Preliminary observations showed that crude extracts of benzoate-grown organisms lost easily $m$-pyrocatechase activity, confirming the instability of this enzyme reported by Kojima, Itada \& Hayaishi (196I). To stabilize this enzyme, 10\% (v/v) of acetone as used by Nozaki, Kagamiyama \& Hayaishi (1963) was added to 20 mM-sodiumpotassium phosphate buffer containing Io $\mu$ M-Mg-EDTA ( $\mathrm{pH} 7 \cdot 5$ ), when harvesting organisms grown on benzoate for which $m$-pyrocatechase activity was to be determined.

Frozen bacterial suspensions were thawed and broken by ultrasonic treatment for 4 min. with a Ioo W Ultrasonic Disintegrator (Measuring \& Scientific Equipment Ltd., London, England). The samples were cooled with ice water during this treatment. The extracts were centrifuged at $50,000 \mathrm{~g}$ for $45 \mathrm{~min}$. at $0^{\circ}$, and the pellets discarded. The supernatant fluids were decanted and used as the crude extracts for measurement of enzyme activity. The protein concentration of the fluids so obtained was between 15 and $20 \mathrm{mg} . / \mathrm{ml}$.

Enzyme assays. All enzymic activities in crude extracts were assayed spectrophotometrically at room temperature (about $21^{\circ}$ ). The unit of activity is defined in all cases as the amount of enzyme necessary to convert one micromole substrate/min. under assay conditions, except the unit of $\beta$-ketoadipate succinyl-CoA transferase activity, which is defined as described by Cánovas \& Stanier (1967).

The enzyme assays were performed by the following published procedures: $p$ hydroxybenzoate hydroxylase (Hosokawa \& Stanier, I966); protocatechuate-3,4oxygenase (Stanier \& Ingraham, 1954); carboxymuconate-lactonizing enzyme and $\beta$-ketoadipate enol-lactone hydrolase (Ornston, $1966 a$ ) $; \beta$-ketoadipate succinyl-CoA transferase by a modification (Cánovas \& Stanier, 1967) of the method of Katagiri \& 
Hayaishi (I957); $m$-pyrocatechase (Kojima et al. I96I); pyrocatechase (Hegeman, I966); muconate lactonizing enzyme and (+)-muconolactone isomerase (Ornston, I $966 \mathrm{~b}$ ). The enzymic activity of each extract was always measured at several different concentrations to establish the linearity of the relationship between activity and concentration. Enzyme concentrations in crude extracts are expressed as units of enzyme/mg. protein.

Chemical measurements. Protein in crude extracts was determined by the method of Lowry, Rosebrough, Farr \& Randall (I95I), with crystalline bovine serum albumin (Nutritional Biochemicals Corporation, Cleveland, Ohio) as standard.

The quantity of $\alpha$-hydroxymuconic semialdehyde formed in cell-free extracts was determined from the extinction at $375 \mathrm{~m} \mu$. The identity of the accumulated $\alpha$-hydroxymuconic semialdehyde was established from the absorption spectrum.

\section{RESULTS}

Utilization of aromatic and hydroaromatic acids as sole sources of carbon and energy

Azotobacter and Beijerinckia strains were tested for ability to grow with benzoate, shikimate and $p$-hydroxybenzoate as carbon + energy sources. All strains of Azotobacter chroococcum, $A$. vinelandii and $A$. beijerinckii grew well with these substrates, whereas $A$. agilis did not. These results are in agreement with previous studies concerning the pattern of utilization of aromatic compounds by Azotobacter species (Tchan, I953). None of the Beijerinckia strains was able to grow at the expense of these compounds.

Table I. Ring cleavage of catechol and protocatechuate by some strains of Azotobacter tested after growth on benzoate and p-hydroxybenzoate

Azotobacter
strains

strains
Cleavage of catechol (organisms grown on benzoate)

$\overbrace{\begin{array}{c}\text { Ortho } \\ \text { cleavage }\end{array}}^{\begin{array}{c}\text { Meta } \\ \text { cleavage }\end{array}}$

A. chroococcum strain IP

A. chroococcum strain $\mathrm{V}$

A. chroococcum strain 203

A. vinelandii

A. vinelandii

A. vinelandii

A. vinelandii

A. beijerinckii

strain $\mathrm{C}-\mathrm{I} 4$ strain C-I 5 strain 206

strain $\mathrm{v}$
Cleavage of protocatechuate (organisms grown on $p$-hydroxybenzoate)

$\overbrace{\begin{array}{c}\text { Ortho } \\ \text { cleavage }\end{array}}^{\begin{array}{c}\text { Meta } \\ \text { cleavage }\end{array}}$

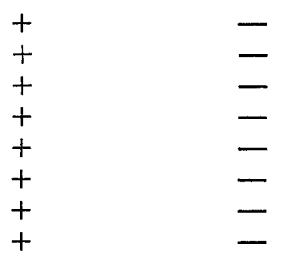

Mechanism of aromatic ring-cleavage

Qualitative tests for the mechanism of aromatic ring-cleavage were performed with the Azotobacter strains able to grow on benzoate and $p$-hydroxybenzoate. As shown in Table $\mathrm{I}$, all the strains examined de-aromatize protocatechuate by ortho cleavage after growth with $p$-hydroxybenzoate, and catechol by meta cleavage after growth with benzoate. Single strains representative of Azotobacter chroococcum (strain 203), A. vinelandii (strain 206) and $A$. beijerinckii (strain v) were selected for further study. 


\section{Growth rates}

The growth rates at $28^{\circ}$ of these three strains with succinate, $p$-hydroxybenzoate, benzoate and shikimate are shown in Table 2 . In every case, growth at the expense of the aromatic and hydroaromatic substrates was considerably slower than growth with succinate.

Table 2. Generation times of Azotobacter strains studied with various compounds as sole sources of carbon and energy

\begin{tabular}{|c|c|c|c|c|c|}
\hline \multirow{2}{*}{\multicolumn{2}{|c|}{$\begin{array}{c}\text { Azotobacter } \\
\text { strains }\end{array}$}} & \multicolumn{4}{|c|}{ Growth substrate } \\
\hline & & Succinate & $\begin{array}{l}p \text {-Hydroxy } \\
\text { benzoate }\end{array}$ & Shikimate & Benzoate \\
\hline & & \multicolumn{4}{|c|}{ Generation times (min.) } \\
\hline Azotobacter chroococcum & strain 203 & I IO & 200 & 205 & 180 \\
\hline A. vinelandii & strain 206 & 135 & 240 & 220 & 180 \\
\hline A. beijerinckii & strain $\mathrm{v}$ & I 80 & 215 & 205 & 190 \\
\hline
\end{tabular}

Table 3. Rates of oxygen uptake $\left(Q_{\mathrm{O}_{2}}\right)$ at the expense of various compounds by Azotobacter chroococcum strain 203*

\begin{tabular}{|c|c|c|c|c|c|c|c|c|}
\hline \multirow[b]{2}{*}{$\begin{array}{l}\text { Organisms } \\
\text { grown with }\end{array}$} & \multicolumn{8}{|c|}{ Rate of oxygen uptake $\left(\mathrm{Q}_{\mathrm{O}_{2}}\right)$ with } \\
\hline & $\begin{array}{l}\text { Succi- } \\
\text { nate }\end{array}$ & $\begin{array}{l}p \text {-Hydroxy- } \\
\text { benzoate }\end{array}$ & $\begin{array}{l}\text { Shiki- } \\
\text { mate }\end{array}$ & $\begin{array}{l}\text { Protoca- } \\
\text { techuate }\end{array}$ & $\begin{array}{c}\beta \text {-Carboxy- } \\
\text { cis,cis- } \\
\text { muconate }\end{array}$ & Benzoate & Catechol & $\begin{array}{l}\beta \text {-Keto- } \\
\text { adipate }\end{array}$ \\
\hline Succinate & I 400 & 6 & 45 & - & - & 38 & - & 60 \\
\hline $\begin{array}{l}p \text {-Hydroxy- } \\
\text { benzoate }\end{array}$ & 190 & 1660 & 210 & 1080 & 60 & - & - & 105 \\
\hline Shikimate & I 65 & 28 & 940 & 1480 & - & - & - & - \\
\hline Benzoate & 185 & - & - & - & - & 1900 & I 680 & 75 \\
\hline
\end{tabular}

Influence of growth substrates on the respiration of aromatic compounds

The attack on benzoate, $p$-hydroxybenzoate and shikimate by all three Azotobacter species was more or less strictly inducible. Succinate-grown organisms respired with these compounds at negligible rates, whereas organisms grown with any one of the three compounds in question oxidized it at a high rate. Growth with shikimate or $p$-hydroxybenzoate induced a high rate of protocatechuate oxidation. $\beta$-Ketoadipate and $\beta$-carboxy-cis,cis-muconate were not respired at significant rates by organisms grown with $p$-hydroxybenzoate or shikimate, suggesting that the whole organism" were impermeable to these later intermediates in the metabolism of protocatechuate. Benzoate-grown organisms respired both benzoate and catechol at high rates. Data for Azotobacter chroococcum strain 203 are shown in Table 3; essentially similar results were obtained with $A$. vinelandii strain 206 and $A$. beijerinckii strain v.

\section{Enzymic activities of cell-free extracts}

The activities of certain enzymes in cell-free extracts prepared from Azotobacter chroococcum, $A$. vinelandii and $A$. beijerinckii after growth with succinate, $p$-hydroxybenzoate, shikimate, protocatechuate and benzoate are shown in Tables 4,5 and 6. 
All three strains behaved in a similar manner. Most of the enzymes assayed were not detected in extracts of succinate-grown organisms; however, carboxy-muconate lactonizing enzyme and $\beta$-ketoadipate succinyl CoA transferase were present at very low but detectable concentrations. The values given for the other enzymes assayed in extracts of succinate-grown organisms represent the smallest concentrations which could have been detected by the assay methods used.

Table 4. The effect of different growth substrates on the specific activities of the $\beta$ ketoadipate pathway enzymes in cell-free extracts of Azotobacter chroococcum strain 203

\begin{tabular}{|c|c|c|c|c|c|}
\hline \multirow[t]{2}{*}{ Enzyme } & Succinate & $\begin{array}{l}p \text {-Hydroxy- } \\
\text { benzoate }\end{array}$ & $\begin{array}{l}\text { Protocat- } \\
\text { echuate }\end{array}$ & Shikimate & \multirow[t]{2}{*}{ Benzoate } \\
\hline & \multicolumn{4}{|c|}{ Enzyme units $/ \mathrm{mg}$. protein in cell-free extracts } & \\
\hline $\begin{array}{l}p \text {-Hydroxybenzoate } \\
\text { hydroxylase }\end{array}$ & $<0.001$ & 0.94 & $<0.001$ & $<0.001$ & $<0.001$ \\
\hline Protocatechuate 3,4 -oxygenase & $<0.003$ & $5 \cdot 29$ & $2 \cdot 32$ & $2 \cdot 22$ & $<0.003$ \\
\hline $\begin{array}{l}\text { Carboxymuconate-lactonizing } \\
\text { enzyme }\end{array}$ & 0.009 & 0.58 & 0.52 & 0.49 & 0.009 \\
\hline Enol-lactone hydrolase & $<0.02$ & 0.88 & 0.94 & 1.03 & $<0.02$ \\
\hline Transferase & 0.002 & 0.39 & $0.4 \mathrm{I}$ & 0.36 & 0.002 \\
\hline Pyrocatechase & $<0.008$ & 0.092 & 0.042 & 0.040 & 0.01 \\
\hline$m$-Pyrocatechase & $<0.004$ & $<0.004$ & - & $<0.004$ & 0.38 \\
\hline Muconate-lactonizing el & $<0.002$ & $<0.002$ & - & $<0.002$ & $<0.002$ \\
\hline Muconolactone isomerase & $<0.01$ & $<0.01$ & - & $<0.01$ & $<0.01$ \\
\hline
\end{tabular}

Table 5. The effect of different growth substrates on the specific activities of the $\beta$ ketoadipate pathway enzymes in cell-free extracts of Azotobacter beijerinckii strain $V$

Substrate used for growth

\begin{tabular}{|c|c|c|c|c|c|}
\hline \multirow[t]{2}{*}{ Enzyme } & Succinate & $\begin{array}{l}p \text {-Hydroxy- } \\
\text { benzoate }\end{array}$ & $\begin{array}{l}\text { Protocat- } \\
\text { echuate }\end{array}$ & Shikimate & Benzoate \\
\hline & \multicolumn{5}{|c|}{ Enzyme units/mg. protein in cell-free extracts } \\
\hline $\begin{array}{l}p \text {-Hydroxybenzoate } \\
\text { hydroxylase }\end{array}$ & $<0.001$ & $0 \cdot 79$ & $<0.001$ & $<0.001$ & $<0.00 \mathrm{I}$ \\
\hline Protocatechuate 3,4 -oxygenase & $<0.003$ & $5 \cdot 44$ & $2 \cdot 44$ & $2 \cdot 36$ & $<0.003$ \\
\hline $\begin{array}{l}\text { Carboxymuconate-lactonizing } \\
\text { enzyme }\end{array}$ & 0.009 & 0.44 & 0.46 & 0.46 & 0.009 \\
\hline Enol-lactone hydrolase & $<0.02$ & $0.8 \mathrm{I}$ & 0.84 & 0.93 & $<0.02$ \\
\hline Transferase & 0.003 & 0.46 & 0.52 & 0.48 & 0.003 \\
\hline Pyrocatechase & $<0.008$ & 0.093 & 0.047 & 0.042 & 0.01 \\
\hline$m$-Pyrocatechase & $<0.004$ & $<0.004$ & - & - & 0.34 \\
\hline Muconate-lactonizing enzyme & $<0.002$ & $<0.002$ & - & - & $<0.002$ \\
\hline Muconolactone isomerase & $<0.01$ & $<0.01$ & - & - & $<0.01$ \\
\hline
\end{tabular}

Growth at the expense of $p$-hydroxybenzoate induced high degrees of activity of $p$-hydroxybenzoate hydroxylase, protocatechuate oxygenase, carboxymuconate lactonizing enzyme, enol-lactone hydrolase and $\beta$-ketoadipate succinyl-CoA transferase. This confirms that the dissimilation of $p$-hydroxybenzoate proceeded through the $\beta$-ketoadipate pathway. The patterns of enzymic activity of organisms grown with shikimate and protocatechuate were qualitatively similar, except that $p$-hydroxy- 
benzoate hydroxylase was not induced. The specific activities of the enzymes of the $\beta$-ketoadipate pathway in shikimate-grown and in protocatechuate-grown organisms were also similar except for the protocatechuate-3,4-oxygenase and pyrocatechase values which were about half those found in $p$-hydroxybenzoate-grown organisms. Growth at the expense of these three substrates also induced a measurable pyrocatechase activity; the product of this reaction, as determined by measurement of its absorption spectrum, was cis,cis-muconate. It is probable that this activity reflected the fact that the protocatechuate oxygenase of these bacteria is non-specific, and can also perform an ortho cleavage of catechol at a very low rate. $m$-Pyrocatechase, which was present at high values in benzoate-grown organisms, was not measurably induced by growth with $p$-hydroxybenzoate, shikimate or protocatechuate.

Table 6. The effect of different growth substrates on the specific activities of the $\beta$ ketoadipate pathway enzymes in cell-free extracts of Azotobacter vinelandii strain 206

\begin{tabular}{|c|c|c|c|c|c|}
\hline \multirow{3}{*}{ Enzyme } & \multicolumn{5}{|c|}{ Substrate used for growth } \\
\hline & Succinate & $\begin{array}{l}p \text {-Hydroxy- } \\
\text { benzoate }\end{array}$ & $\begin{array}{l}\text { Protocat- } \\
\text { echuate }\end{array}$ & Shikimate & Benzoate \\
\hline & \multicolumn{5}{|c|}{ Enzyme units/mg. protein in cell free extracts } \\
\hline $\begin{array}{l}p \text {-Hydroxybenzoate } \\
\text { hydroxylase }\end{array}$ & $<0.001$ & 0.48 & $<0.001$ & $<0.001$ & $<0.001$ \\
\hline Protocatechuate 3,4 -oxygenase & $<0.003$ & $5 \cdot 33$ & $2 \cdot 21$ & $2 \cdot 40$ & $<0.003$ \\
\hline $\begin{array}{l}\text { Carboxymuconate-lactonizing } \\
\text { enzyme }\end{array}$ & 0.009 & $0.9 \mathrm{I}$ & 0.92 & 0.89 & 0.009 \\
\hline Enol-lactone hydrolase & $<0.02$ & 0.78 & 0.82 & 0.96 & $<0.02$ \\
\hline Transferase & 0.002 & 0.20 & 0.23 & 0.19 & 0.002 \\
\hline Pyrocatechase & $<0.008$ & 0.086 & 0.038 & 0.042 & 0.02 \\
\hline$m$-Pyrocatechase & $<0.004$ & $<0.004$ & - & - & 0.57 \\
\hline Muconate-lactonizing enzyme & $<0.002$ & $<0.002$ & - & - & $<0.002$ \\
\hline Muconolactone isomerase & $<0.01$ & $<0.01$ & - & - & $<0.01$ \\
\hline
\end{tabular}

Of the enzymes assayed, the only one present at high values in benzoate-grown organisms was $m$-pyrocatechase. It should be noted that muconate-lactonizing enzyme, muconolactone isomerase, enol-lactone hydrolase and transferase, all required for the dissimilation of catechol through the $\beta$-ketoadipate pathway, were not measurably induced by growth with benzoate; this showed that benzoate dissimilation must proceed, in all three species, exclusively through the meta cleavage pathway.

\section{Properties of Azotobacter chroococcum $p \beta-203$, a permeability mutant}

Wild-type organisms of the three Azotobacter strains studied cannot grow with $\beta$-ketoadipate, and respirometric data showed that $p$-hydroxybenzoate-grown organisms were impermeable to $\beta$-ketoadipate and $\beta$-carboxy-cis,cis-muconate. Spontaneous mutants with increased permeability to $\beta$-ketoadipate were obtained from Azotobacter chroococcum strain 203. The respiratory behaviour of one of these mutants, $\mathrm{p} \beta$-203, showed that mutation had rendered it permeable to $\beta$-ketoadipate but not to $\beta$-carboxy-cis,cis-muconate (Fig. I).

Table 7 shows the values for protocatechuate pathway enzymes in crude extracts of mutant $\mathrm{p} \beta-203$ grown with succinate and with $\beta$-ketoadipate. The enzymic constitution of $\mathrm{p} \beta-203$ after growth with succinate was identical with that of the wild type 
grown with the same substrate. Growth of mutant $\mathrm{p} \beta$-203 with $\beta$-ketoadipate elicited high transferase and enol-lactone hydrolase values. The value of carboxymuconatelactonizing enzyme increased about 3 -fold over the basal value, but this increase was probably not significant. $p$-Hydroxybenzoate hydroxylase and protocatechuate-3,4oxygenase were not induced by growth with $\beta$-ketoadipate.

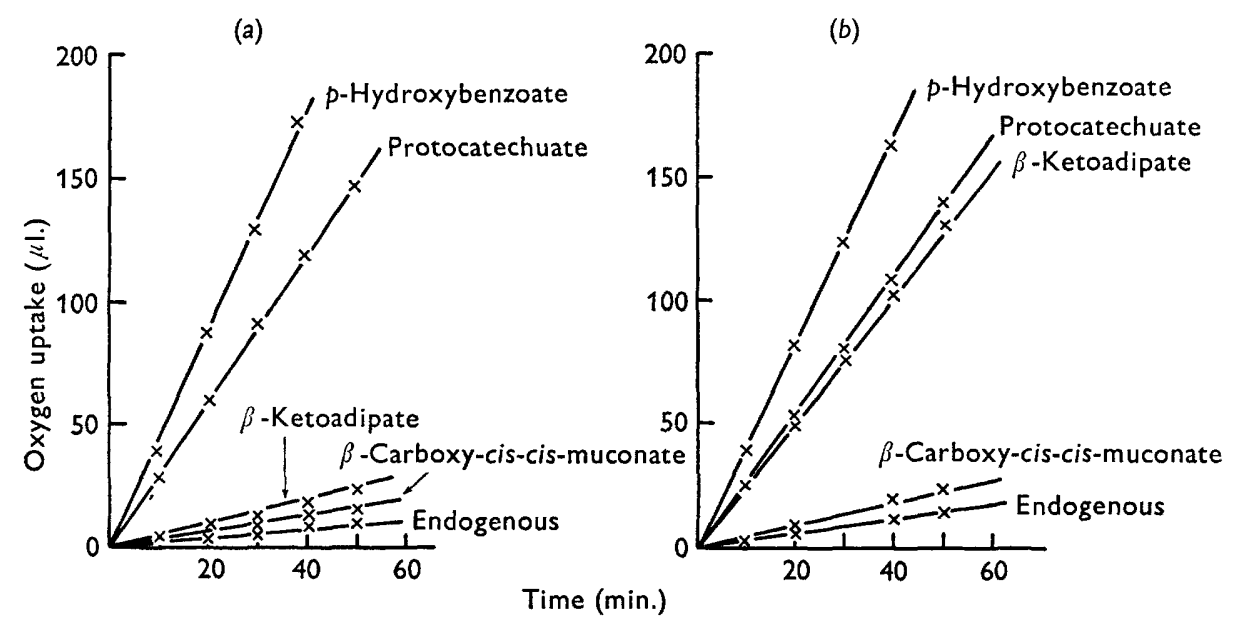

Fig. I. The rates of oxidation of $p$-hydroxybenzoate, protocatechuate, $\beta$-carboxy-cis,cismuconate and $\beta$-ketoadipate by cells of Azotobacter chroococcum strain $203(a)$ and a permeability mutant, strain $\mathrm{p} \beta-203(b)$ both grown on $p$-hydroxybenzoate.

Table 7. Enzyme values in cell-free extracts of Azotobacter chroococcum strain p $\beta 203$, a permeability mutant, after growth on $\beta$-ketoadipate and succinate

$$
\text { Enzyme } \overbrace{\begin{array}{c}
\text { Succinate } \\
(20 \mathrm{mM})
\end{array}}^{\text {Substrate used for growth }}
$$

\begin{tabular}{|c|c|}
\hline Substrate & for growth \\
\hline $\begin{array}{c}\text { Succinate } \\
\text { (20 mM) }\end{array}$ & $\begin{array}{c}\beta \text {-Ketoadipate } \\
\quad(\text { Io } \mathrm{mM})\end{array}$ \\
\hline nzyme units/mg. pr & in cell-free ext \\
\hline$<0.001$ & $<0.001$ \\
\hline$<0.003$ & $<0.003$ \\
\hline 0.009 & 0.027 \\
\hline$<0.02$ & $1 \cdot 17$ \\
\hline 0.0025 & 0.30 \\
\hline
\end{tabular}

p-Hydroxybenzoate hydroxylase Protocatechuate 3,4-oxygenase

Carboxymuconate lactonizing enzyme Enol-lactone hydrolase

Transferase

Induced enzymic activities in vegetative forms and cysts

Both Azotobacter chroococcum and A. beijerinckii produce the specialized resting forms known as cysts (Winogradsky, 1938). A culture of $A$. beijerinckii strain v, growing with $p$-hydroxybenzoate, was harvested after massive cyst formation had occurred, and the activities of four inducible enzymes were assayed in parallel with assays of the same enzymes in vegetative forms (Table 8). It can be seen that relatively high values of these four enzymes (about half the values characteristic of vegetative forms) were found in the cysts. 


\section{Co-factor requirements of p-hydroxybenzoate hydroxylase}

Experiments made with crude extracts of $p$-hydroxybenzoate-grown organisms (Table 9) suggested that the $p$-hydroxybenzoate hydroxylase of the three Azotobacter species is a NADPH-dependent oxygenase. The enzyme was wholly inactive with NADH. As in the case of the $p$-hydroxybenzoate hydroxylase of Pseudomonas putida (studied by Hosokawa \& Stanier, 1966), FAD was a co-factor and seemed to be tightly bound to the enzyme; FMN was inhibitory. In tris $\mathrm{HCl}$ buffer $(\mathrm{pH} 8 \cdot 0)$ was the optimal value for enzyme activity.

Table 8. Relative activities of the enzymes of the p-hydroxybenzoate pathway in cellfree extracts of rod-shaped vegetative forms and cysts of Azotobacter beijerinckii strain $\checkmark$ grown on p-hydroxybenzoate

Activities in cell-free extracts of vegetative forms are taken as 100

\begin{tabular}{lcc} 
Enzyme & Relative activity in crude extract of: \\
\cline { 2 - 3 }$p$-Hydroxybenzoate hydroxylase & 100 & Cysts \\
Protocatechuate 3,4 -oxygenase & 100 & 48 \\
Carboxymuconate lactonizing enzyme & 100 & 56 \\
Enol-lactone hydrolase & 100 & 60
\end{tabular}

Table 9. Effect of reduced pyridine nucleotide and flavine derivatives on activity of $p$ hydroxybenzoate hydroxylase in crude extracts of p-hydroxybenzoate-grown organisms*

Relative activitiest of $p$-hydroxybenzoate hydroxylase under the

Azotobacter strains standard assay conditions with

\begin{tabular}{|c|c|c|c|c|c|c|c|}
\hline \multicolumn{2}{|c|}{ Azotobacter strains } & & \\
\hline & & NADPH & NADH & $\begin{array}{l}\text { NADPH } \\
+ \text { FAD }\end{array}$ & $\begin{array}{l}\text { NADH } \\
+ \text { FAD }\end{array}$ & $\begin{array}{c}\text { NADPH } \\
+ \text { FMN }\end{array}$ & $\begin{array}{l}\text { NADH } \\
+ \text { FMN }\end{array}$ \\
\hline A. chroococcum & strain 203 & 84 & 6 & 100 & 9 & 13 & 0 \\
\hline A. vinelandii & strain 206 & 85 & 4 & 100 & 5 & 17 & 0 \\
\hline A. beijerinckii & strain $\mathrm{v}$ & 96 & 3 & IOO & 3 & 17 & 0 \\
\hline
\end{tabular}

* Assay conditions were the same as described by Hosokawa \& Stanier (1966).

$\dagger$ Activities under standard assay conditions with NADPH + FAD are taken as 100.

Table Io. The stoichiometry of $\alpha$-hydroxymuconic semialdehyde formation from catechol by cell-free extracts of Azotobacter strains grown with benzoate

Experimental conditions were the same as described in Methods except that 100 mM-sodium potassium phosphate buffer ( $\mathrm{pH} \mathrm{7.5)}$ was used; $5 \mu$ mole catechol and $0.1 \mathrm{ml}$. of cell-free extract (equiv. $10 \mathrm{mg}$. protein $/ \mathrm{ml}$.) were used. The quantity of product formed was determined from absorbance at $375 \mathrm{~m} \mu$.

Micromoles

\section{Azotobacter strains}

$\begin{array}{ll}\text { A. } \text { chroococcum } & \text { strain } 203 \\ \text { A. vinelandii } & \text { strain } 206 \\ \text { A. beijerinckii } & \text { strain v }\end{array}$

\begin{tabular}{|c|c|c|}
\hline Catechol provided & Oxygen consumed & $\begin{array}{l}\alpha \text {-Hydroxymuconic } \\
\text { semialdehyde formed }\end{array}$ \\
\hline $5 \cdot 0$ & $4 \cdot 6$ & $4 \cdot 8$ \\
\hline $5 \cdot 0$ & $4 \cdot 7$ & $5 \cdot 04$ \\
\hline $5 \cdot 0$ & $4 \cdot 5$ & $4 \cdot 7$ \\
\hline
\end{tabular}




\section{Stoichiometry of the reaction catalyzed by m-pyrocatechase}

Crude cell-free extracts of all three Azotobacter strains grown with benzoate catalysed a quantitative meta cleavage of catechol, with accumulation of $\alpha$-hydroxymuconic semialdehyde, the immediate product (Table I0). We did not attempt to detect or assay any subsequent enzymes of the meta cleavage pathway.

\section{DISCUSSION}

The results reported here show that the three species of the Azotobacter group capable of utilizing benzoate and $p$-hydroxybenzoate metabolize these two acids through completely different metabolic pathways. The $\beta$-ketoadipate pathway, used by fluorescent pseudomonads (Stanier et al. 1966) and oxidase-negative moraxellas (Cánovas \& Stanier, 1967) for the dissimilation of both these substrates, serves in the Azotobacter group only for the dissimilation of $p$-hydroxybenzoate and of the metabolically related hydro-aromatic acid, shikimate, which is also dissimilated through the protocatechuate branch of the $\beta$-ketoadipate pathway. Benzoate, on the other hand, is metabolized, after conversion to catechol, exclusively through the meta cleavage pathway. None of the enzymes operative in catechol dissimilation through the $\beta$-ketoadipate pathway is induced in benzoate-grown Azotobacter organisms. This metabolic pattern has not been reported in any other group of aerobic bacteria capable of growth at the expense of benzoate and $p$-hydroxybenzoate, and therefore appears to constitute a taxonomically significant biochemical property of the Azotobacter group.

As in all other bacteria so far examined, the utilization by the Azotobacter group of aromatic compounds is mediated by strictly inducible enzymes. Our observations on the patterns of induction, though preliminary, suggest that the regulation of the enzymes of the $\beta$-ketoadipate pathway in Azotobacter may be distinct from the patterns of regulation described in fluorescent pseudomonads (Ornston, 1966c; Kemp \& Hegeman, 1968) and in Acinetobacter (Moraxella) calcoacetica (Cánovas \& Stanier, 1967). The properties of a permeability mutant of Azotobacter chroococcum suggest that $\beta$-ketoadipate can act as an inducer of $\beta$-ketoadipate enol-lactone hydrolase and $\beta$-ketoadipate succinyl-CoA transferase, but not of carboxymuconate lactonizing enzyme. In Acinetobacter calcoacetica $\beta$-ketoadipate induces none of these enzymes; in Pseudomonas putida it induces all three.

Our data indicate that the ability to utilize benzoate, $p$-hydroxybenzoate and shikimate as sources of carbon + energy is a useful nutritional character for distinguishing Azotobacter chroococcum, $A$. vinelandii and $A$. beijerinckii from $A$. agilis, which can utilize none of them. We have also found that the Beijerinckia strains examined are unable to use these aromatic and hydro-aromatic components as growth substrates.

We express our thanks to Dr G. D. Hegeman for supplying the purified enzymes used. We are also grateful to Dr M. Robert-Gero who kindly provided certain of the chemicals necessary for this study. Jose M. Sala-Trapat was a recipient of a grant from the Spanish 'Ministerio de Educación y Ciencia'. R. Y. Stanier was a Fellow of the J. S. Guggenheim Memorial Foundation. 


\section{REFERENCES}

Burk, D. \& Lineweaver, H. (1930). The influence of fixed nitrogen on Azotobacter. J. Bact. 19, 389.

CÁnovas, J. L. \& Stanier, R. Y. (1967). Regulation of the enzymes of the $\beta$-ketoadipate pathway in Moraxella calcoacetica. I. General aspects. Europ. J. Biochem. x, 289.

Dagley, S., Evans, W. C. \& Ribbons, D. W. (I960). New pathways in the oxidative metabolism of aromatic compounds by micro-organisms. Nature, Lond. 188, 560.

DeLey, J. \& PARK, I. W. (1966). Molecular biological taxonomy of some free-living nitrogen fixing bacteria. Antonie van Leeuwenhoek 32, 6.

Guittonneau, G. \& Chevalier, R. (1939). Sur l'attaque des noyaux benzeniques et l'utilisation alimentaire du phenol par les Azotobacter du sol. C.r. hebd. Séanc. Acad. Sci., Paris 206, 863.

Hegeman, G. D. (I966). Synthesis of the enzymes of the mandelate pathway by Pseudomonas putida. I. Synthesis of enzymes by the wild type. J. Bact. 9r, 1140.

Hosokawa, K. \& Stanier, R. Y. (1966). Crystallization and properties of p-hydroxybenzoate hydroxylase from Pseudomonas putida. J. biol. Chem. 241, 2453.

KataGiRI, M. \& HaYAISHI, O. (1957). Enzymatic degradation of $\beta$-ketoadipic acid. J. biol. Chem. 226, 439 .

Kemp, M. B. \& Hegeman, G. D. (1968). Genetic control of the $\beta$-ketoadipate pathway in Pseudomonas aeruginosa. J. Bact. 96, 1488.

Kojima, Y., Itada, N. \& HayAishi, O. (I961). Metapyrocatechase: a new catechol-cleaving enzyme. J. biol. Chem. 236, 2223.

Lowry, O. H., Rosebrough, N. J., FARr, A. L. \& Randall, R. J. (195I). Protein measurement with the Folin phenol reagent. J. biol. Chem. 193, 265.

Nozaki, M., KagamiYama, H. \& Hayaishi, O. (I963). Metapyrocatechase. I. Purification, crystallization and some properties. Biochem. $Z$. 338, 582 .

ORNSTON, L. N. (1966a). The conversion of catechol and protocatechuate to $\beta$-ketoadipate by Pseudomonas putida. II. Enzymes of the protocatechuate pathway. J. biol. Chem. 24r, 3787 .

ORNSTON, L. N. (1966 b). The conversion of catechol and protocatechuate to $\beta$-ketoadipate by Pseudomonas putida. III. Enzymes of the catechol pathway. J. biol. Chem. 241, 3795 .

ORNSTON, L. N. $($ I $966 c)$. The conversion of catechol and protocatechuate to $\beta$-ketoadipate by Pseudomonas putida. IV. Regulation. J. biol. Chem. 24I, 3800.

Ribbons, D. W. (1966). The microbiological degradation of aromatic compounds. Ann. Reports Chem. Soc. 62, 445 .

Stadtman, E. R. (1957). Preparation and assay of acylcoenzyme A and other thiol esters; use of hydroxylamine. Meth. Enzymol. 3, 931 .

Stanier, R. Y. \& Ingraham, J. L. (1954). Protocatechuic acid oxidase. J. biol. Chem. $210,799$.

Stanier, R. Y., Palleroni, N. J. \& Doudoroff, M. (I966). The aerobic pseudomonads: a taxonomic study. J. gen. Microbiol. 43, I59.

Tchan, Y. T. (1953). Taxonomy of the genus Azotobacter. Proc. Linn. Soc. N. S. W. 78, 85 .

VOETS, J. P. (1958). The oxidation of benzoic acid by Azotobacter. Naturwissenschaften 45, 386.

Winogradsky, S. (1932). Sur la synthèse de l'ammoniaque par les Azotobacter du sol. Annls Inst. Pasteur, Paris 48, 269.

Winogradsky, S. (1938). Sur la morphologie et l'oecologie des Azotobacter. Annls Inst. Pasteur, Paris 60, 35 I. 